\title{
Protective Effect of Nettle and Olive Leaves on Hyperlipidemia in Experimental Rats
}

\author{
Aya Salah Elden Mohamed Anies Hafeez, Suzan A.E. Saad and Suzan S. \\ Ibraheim*
}

\begin{abstract}
Nutrition and Food Science Dept., Faculty of Home Economics, Al-Azhar University, Egypt *Corresponding Author, Suzan Sami Ibraheim

Email:suzansamiibraheim@azhar.edu.eg
\end{abstract}

\section{ABSTRACT}

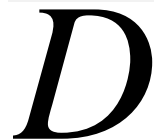

yslipidemia is a major contributor to atherosclerotic cardiovascular disease. Recently, World Health Organization (WHO) reported that cardiovascular diseases (CVD) account for $46 \%$ of ever all mortality in Egypt. So that; the present study investigated, the protective effect of nettle and olive leaves on hyperlipidemia in experimental rats. Thirty six male albino rats weighing $130 \pm 20 \mathrm{~g}$ used in this study and divided into equal six groups ( 6 rats each), the first kept as anegative control group (-ve) received basal diet throughout the experiment period, while the second was the (+ve) control group which fed on hyperlipidemic diet for four weeks, while the four others groups given hyperlipidemic diet supplemented with nettle leaves (5\%),(10\%) and olive leaves $(5 \%),(10 \%)$ respectively for four weeks (astreatment groups). The chemical composition and phenolic compounds of both leaves were done. At the end of the experiment, biological data were calculated; blood samples were taken to biochemical analysis. In addition, histopathological examination was done. The results revealed that hyperlipidemic diet in the (+ve) control group increased body weight gain, relative organ weight, serum lipid profile, Malondialdhyde (MDA), liver enzymes and serum glucose, decreased in serum HDL-C, serum Superoxide Dismutase (SOD), and Glutathione Peroxidase (GPx). All treated groups with two leaves showed improvement previously parameters compared with positive control group. In conclusion, the consumption of nettle and olive leaves could be used for improving lipid profile, liver function and protect from hyperlipidemia in experimental rats.

Key words: lipid profile- nettle - olive - leaves - antioxidant enzymes-liver function 


\section{INTRODUCTION}

Hyperlipidemia (HLD) is a condition that incorporates various genetic and acquired disorders that describe elevated lipid levels within the human body (Hill and Bordoni, 2021). HLD is characterized by high levels of low-density lipoprotein cholesterol (LDL-C) or high triglycerides (TG), and plays an important role in the pathogenesis of cardiovascular diseases ( $\mathbf{L i}$ et $\boldsymbol{a l}$., 2021).

From ages, human diseases are treated by herbal medicines in almost every infection. In modish age, it choice to make use of them instead of the synthetic ones as there are fewer side effects of traditional medicines .Plants are natural source of treatment and are used from ages for food and medicine (Shah et al., 2021). Herbal plants have also been found to nourish the body and provide vitamins, minerals, and many trace elements that are easy to absorb (Melkegna and Jonah, 2021).

Stinging nettle (Urticadioica L.) is a perennial herb with a long history of traditional medicinal uses in many countries.Nettle leaves are rich in chlorophyll, carotenoids, vitamins, proteins, fats, carbohydrates, organic acids, minerals, and trace elements. The leaves of stinging nettle contain abundant amounts of natural phenolic compounds, which may function as effective natural antioxidants (Paulauskienè et al., 2021). This herb has a history of use in traditional medicine to treat diverse conditions including lipid disturbances. Positive effect of Urticadioica $L$. against lipid derangements has been demonstrated in vivo studies (Namazi et al., 2018).

Olive tree leaves have been widely used as traditional remedies to cure several diseases Chemical characterization analysis revealed that olive tree leaves contain several bioactive compounds that may exert beneficial effects in certain morbidities such as metabolic syndrome, and hypertension (Ranieri et al., 2021).

Since little information is available regarding the preventive influences of Uritcadioica L. and Oleaeuropaea L. leaves, on hyperlipidemia in vivo, this study was carried out.

\section{MATERIALS \& METHODS}

Plant materials: 
Dry Uritcadioica $L$. and Oleaeuropaea $L$. leaves were purchased from The Local Company for Herbs and Medicinal Plants, Cairo Governorate, Egypt.

\section{Preparation of plant:}

Dry Uritcadioica L. and Oleaeuropaea L. leaves were homogenized in the blender then stored at room temperature in closed glass bottles in the dark until using.

\section{Animals:}

Thirty-six adult male albino rats Sprague Dawley strain weighing $(130 \pm 20 \mathrm{~g})$ were housed in wellaerated cages under hygienic condition and were fed on basal diet for one week to adapt.

\section{Methods:}

\section{Chemical analysis}

- Chemical composition (protein, fat, moisture, ash and carbohydrates calculated by difference) determined according to (A.O.A.C, 2010).

- Phenolic compounds and flavonoids of both powder evaluated by method of Tarola et al., (2013).

Experimental design:
The Animals were divided into equal six groups. The first group (6 rats) fed on basal diet according to Reeves et al., (1993), and served asa negative control group (-ve) control, while the second was the (+ve) control group which fed on hyperlipidemic diet for four weeks according to Rashwan (1994), the third and fourth groups fed on hyperlipidemic diet supplemented with nettle leaves powders (5\%) and (10 \%) respectively. The fifth and sixth groups fed on hyperlipidemic diet supplemented with olive leaves powders $(5 \%)$ and (10 \%) respectively for four weeks (astreatment groups). At the end, animals were weighed, fasted overnight, and then sacrificed after anesthesia ones this. Blood samples will be was collected from hepatic portal vein of each rat into dry clean centrifuge tubes. Serum was carefully separated by centrifugation of blood samples at $3500 \mathrm{rpm}$ (round per minute) for 15 minutes at room temperature, transferred into dry clean Eppendorf tubes, then kept frozen at $-20^{\circ} \mathrm{C}$ for latter determinations. Liver, kidney and hearthas been removed from rats by careful dissection and washed in saline solution $(0.9 \%)$, dried using 
filter paper and independently weighed.

\section{Biological evaluation}

During the experiment (28days), feed intake was recorded every day and body weight was recorded every week. Biological evaluation of the different diets was carried out by calculating of body weight gain \% (BWG \%) and feed efficiency ratio (FER) according to Chapman et al., (1959).

\section{Biochemical analysis of serum}

Serum was analyzed for various biochemical parameters like lipid profile, total cholesterol, triglycerides and HDL-C were evaluated on the authority of Allain et al., (1974); Trinder and Ann, (1969) and Lopes -Virella et al., (1977) but LDL-C and VLDL-C calculated as claimed by Friedwald et al., (1972). The atherogenic indexe was calculated as stated by Tilvis and Miettinen (1986). Antioxidant enzymes super oxide dismutase (SOD), glutathione peroxidase (GPx) and Malondialdehyde (MDA) level as a parameter for the lipid peroxidation were evaluated in the opinion of Kakkar et al., (1984), Ellman (1959) and Draper et al ., (1993).
Aspartate aminotransferase (AST), Alanine aminotransferase (ALT), Alkalinephosphatase (ALP) were measured on the report of Bergmeyer et al., (1986) and Roy, (1970). Glucose was estimated in the serum as maintained by Trinder (1959).

\section{Histopathology investigation}

The heart and liver were fixed in $10 \%$ buffered neutral formalin immediately following excision from animals. Fixed tissues were subsequently processed for histopathology examinations as previously described by Carleton (1979).

\section{Statistical analysis}

Results are expressed as mean \pm standard deviation (SD). Differences between means indifferent groups were tested for significance using a one-way analysis of variance (ANOVA) followed by Duncan's test and probability value of 0.05 or less was considered significant. Comparative of means were performed according to least significant differences test (LSD) according to (Snedecor, 1969) using SPSS (version 20). 


\section{RESULTS \& DISCUSSION}

Table (1) showed the averages $(\mathrm{g})$ of moisture, protein, fat, carbohydrate and ash (g/100gm) in nettle and olive leaves powder. The results of chemical composition for nettle revealed that ashrecorded the highest average followed by carbohydrate, crude protein, fiber, moisture and crude fat respectively. While, the results of chemical composition for olive leaves powder revealed that carbohydrate recorded the highest average followed by fiber, crude protein, ash, moisture and crude fat respectively. These results agree with Maria et al., (2019)who revealed that carbohydrates, protein and minerals of nettle leaves powder were high. While, moisture and crude fat contents were relatively low. Salama et al., (2020) who reported that the olive leaves powder have high carbohydrate, Crude protein contents while moisture and crude fat contents were relatively low.

Data in table (2) clarified the nettle leaves powder recorded the higher content from Benzoic acid, rosemarinic, Neringein, Myricetin, 3-Hydroxytyrosol, Quercitin, Resvertol, p- Hydroxy benzoic acid, Catechol, Ellagic,
Kampherol and Quinol , oCoumaric acid, Catechin, Syringic acid ,Gallic acid, Ferulic acid, Cinnamic acid as shown in fig.(1). This is accordance with Repajić $\boldsymbol{e t}$ al., (2021) who reported that nettle leaves accumulate higher amounts of polyphenols and chlorophylls. In general, leaves are the richest part of a nettle in bioactive compounds; therefore, they are mostly used in processing.

Statistical data in table (3) observed the olive leaves powder recorded the higher content from rosemarinic, Ellagic, Quercitin ,Myricetin, Benzoic acid, Rutin, Kampherol, Resvertol, 3-, Catechol, p- Hydroxybenzoicacids, Caffeic acid, Vanillic acid, Chlorogenic ,Ferulic acid ,cinnamic acid as shown in fig. (2). This is accordance with Ghanem et al ., (2019) who reported that Chemically, leaves of olive contain considerable biophenols such as the other parts of the olive tree Oleuropein and its metabolites, including tyrosol and hydroxytyrosol, are the most abundant phenolic compounds known in the olive leaf. Oleuropein has antibacterial, antiviral, antitumor, blood pressure, and blood lipid-reducing factor, anticancer, and 
cardio-protective activities.

In table (4) hyperlipidemic control (+ve) group revealed more BWG $\%$, FI and FER compared with the control (-ve). All hyperlipidemic rats fed on olive and nettle leaves showed significant decreases in mean values as compared to control (+ve) group. The mean value of (FI) control (-ve) group was lower than control (+ve) group, being $20.95 \pm 2.38$ and 23.23 \pm 2.94 respectively, the best results for FI (g/day) recorded by group fed on olive leaves $10 \%$ which closed to normal group. It could be noticed that the mean value of FER of control (-ve) group was higher than control (+ve) group, being .087 \pm .02 and $0.15 \pm .02$ respectively, the best results for FER recorded by hyperlipidemic rats fed on Nettle 5\%being.0.14 \pm .015 . This result is harmony with Fan et al., (2020) who reported that the high fat (HF) diet supplemented with $U$. dioica (HFUT) had significantly reduced weight gain compared to the HF diet over the 12 weeks. $U$. dioica protects against diet-induced obesity through mechanisms involving lipid accumulation and glucose metabolism in skeletal muscle, liver, and adipose tissue. It may be due to the U. dioica are likely attributed to the high fiber content, phytochemical components, high protein content.

The finding in table (5) suggest that, significant $(\mathrm{p} \leq 0.05)$ increased in (cholesterol and triglyceride ) in (+ve) control group compared with (-ve) control group. While, these parameters decreased in all treated groups especially Olive $10 \%$ and Nettle $10 \%$. On the other hand, HDL parameter recorded high increase in Olive $10 \%$ followed by Nettle 10\% group. These results agree with Eldamaty, (2018) who observed that the Urticadioica leaves powder has lowered the levels oflipids and lipoproteins in blood. The significant decrease was found in lipid profile as total cholesterol, cholesterol fractions and LDL/HDL ratios via lower concentrations of LDL. On the other hand, these results agree with Fki $\boldsymbol{e t}$ al ., (2020) who indicated the hypolipidemic effect of the olive leaf phenolic in high-fat and highcholesterol diet rats It is mainly due to the typical phenolic composition linked to potent biological activities - The major active component in olive leaves is oleuropein.

Results in table

revealed that, significant ( $\mathrm{p} \leq 0.05$ ) increased in (LDL, VLDL and AI) 
in (+ve) control group compared with (-ve) control group. While, these parameters decreased in all treated groups especially Olive $10 \%$ and Nettle $10 \%$. On the other hand, HDL parameter recorded high increase inOlive $10 \%$ followed by Nettle 10\%group . Leaves of olive might be an excellent and promising source of bioactive-compounds, which in turn have high antioxidative properties as reported by Elmaadawy and Alsadeq (2015). Also, these results agree with Eldamaty, (2018) observed that the Urticadioica leaves powder has lowered the levels of lipids and lipoproteins in blood; this is due to that the uniquely high level of polyphenols inUrticadioica leaves may play an important role in contributing to the health benefit such as lowering cholesterol and hyperlipidmia level. The protective effect of U. dioica leaf hydroalcoholic extract against atherosclerosis in rats. Atherosclerosis was experimentally induced in the laboratory by highfat diet atherosclerotic rats (UD) that received $100 \mathrm{mg} / \mathrm{kg} /$ day of ethanolic extract of UD orally. Authors showed, through histopathological evaluations of the aortic arch, that UD group had an improvement of atherosclerotic. UD significantly reduced medial $(\mathrm{p}<0.05)$ but not intimal thickness. The LDL-C/HDL-C ratio significantly decreased in UD groupas reported by (Grausoet al., 2020). More than hypolipidemic effects of olive leaf extracts have been proved in a number of studies. It was found that 50 and $100 \mathrm{mg} / \mathrm{kg} /$ day doses of olive leaf extract may positively affect atherosclerosis by decreasing total cholesterol and low-density lipoprotein (LDL) cholesterol levels in rats (Tek and Ăgagündüz 2020).

Biomarker data in table (7): showed that, significant $(\mathrm{p} \leq 0.05)$ decreased in (SOD and GPx) in (+ve) control group compared with ( -ve) control group. While, MDA was increased in (+ve) control group. However, the reverse recorded for treated groups especially Olive $10 \%$ and Nettle $10 \%$. This significant observation could be explained by the capacity of oleuropein to reduce free radical accumulation, generated after the lipid per-oxidation (Jemai et al., 2020). These results agree with Telo et al., (2017) who administrated that the group fed 
withnettle showed a slight increase in SOD and GPx activities and decreased in the lipid peroxidation.

Liver function enzymes in table (8): showed that, significant ( $\mathrm{p}$ $\leq 0.05)$ increase in (AST, ALT and ALP) in (+ve) control group compared with (-ve) control group. While, these parameters decreased in all treated groups especially Olive $10 \%$ and Nettle $10 \%$.Similar results were obtained by Shaheen and Elkersh (2019) who revealed that, olive leaf extract had very high phenol content and possess strong antioxidant activity administration, which resulted in improved serum ALT , AST and ALP activities and increased serum total antioxidant capacity. So, the improving effect of olive may related to its antioxidant activity Hepatoprotection is the ability to prevent damage to the liver, prevent the liver affections prophylactically and maintains balance in liver enzymes as reported by Eldamaty, (2018) who showed that diabetics rat fed on Urticadioica leaves in basal diet were decreasedin AST and ALT compared with control positive.

Data of glucose analysis in table (9) revealed that, significant ( $p$ $\leq 0.05$ ) increase in Serum Glucose in (+ve) control group compared with (-ve) control group. While, this parameter decreased in treated groups especially Olive 10\% and Nettle 10\%. These results agree with Fan et al., (2020) revealed that U. dioica reduced fasting glucose determined by glucometer. Also Eldamaty, (2018) reported that Stinging nettle (Urticadioica) has a great medicinal value such as relieve of lowering glucose in blood. In the other study revealed that olive leave extracts ameliorated the level of glucose as reported by Sakr et al., (2016) who concluded that theameliorative effect of olive leave extracts againsttoxicity of diabetes in rats may be attributed to thepresence of its phenolic compounds.

\section{Histopathological examination of} liver tissue:

This study examined the effect of high fat high on liver tissues using histological examination. Present results indicated that, Microscopic pictures of $H \& E$ stained liver sections showing normal hepatic architecture with radially arranged hepatic cords around central veins (CV) with normal portal areas (PA) and sinusoids in control normal group as 
shown in photo ( 1 ). Liver sections of (+ve) group showing highly disrupted hepatic architecture due to diffuse ballooning degeneration (black arrows) with multifocal necrosis (blue arrows) of hepatocytes, portal inflammation (yellow arrows)Low magnification $\mathrm{X}: 100$ bar 100 and high magnification $\mathrm{X}: 400$ bar 50 as shown in photo ( 2 ). These results agree with Giammanco et al., (2016) examined the histological sections of liver tissue from high fat diet rats. Note the widespread intracellular vacuolization of hepatocytes and the resulting relocation of cell nuclei in a peripheral position. This results agree with Lasker et al ., (2019) who showed that the hepatic tissue from the control group revealed a normal architecture of hepatocytes, with no appearance of lipid/fat deposition and inflammatory cell infiltration, whereas HF diet-fed groups showed degenerative changes in hepatocyte along with lipid/fat droplet deposition and inflammatory cell infiltration.

While the group which received olive 5\% showing mildly disrupted hepatic architecture due to moderate per portal hydropic degeneration (black arrows) of hepatocytes and mild lobular inflammation (yellow arrows)as shown in photo (3). Liver sections from group received $10 \%$ olive showing greatly restored hepatic architecture with few cytoplasmic vacuoles (black arrows) in hepatocytes around PAas shown in photo (4). Liver sections from group received nettle $5 \%$ showing moderately disrupted hepatic architecture due to hydropic degeneration (black arrows) and large cytoplasmic vacuoles in hepatocytes (red arrows) around CV and PAas shown in photo ( 5 ). Liver sections from group received nettle $10 \%$ showing partially restored hepatic architecture with few minute cytoplasmic vacuoles in hepatocytes around CV (red arrows) and mild hydropic degeneration in hepatocytes (black arrows) around PA. Low magnification X: 100 bar 100 and high magnification X: 400 bar 50. As shown in photo (6). This results agree with Omagari et al., (2021) reported that Oleuropein, an active constituent of olive leaf, have protective effects against nonalcoholic fatty liver disease (NAFLD) in vivo. The oleuropein with which the HFD was supplemented reduced the hepatic mRNA level of the genes that 
encoded the key regulators of the hepatic fatty acid uptake and transport. In addition, the oleuropein reduced the expression of a number of hepatic genes involved in the oxidative stress responses and detoxification of lipid peroxidation products and pro-inflammatory cytokine genes. These results agree with Fan et al., (2020) who concluded that $U$. dioica protects against diet induced obesity through mechanisms involving lipid accumulation and glucose metabolism in skeletal muscle, liver, and adipose.

\section{Histopathological examination of}

\section{Heart tissue:}

This study examined the Effect of high fat high on Heart tissues using histological examination. Our results indicate that,: Microscopic pictures of $\mathrm{H} \& \mathrm{E}$ stained heart sections showing normal longitudinally and crossly sectioned cardiac muscle fibers with normal blood vessels and interstitial tissue in control normal groupas shown in photo ( 1 ). Heart sections of +ve group showed congested blood vessels (red arrows), marked perivascular edema (blue arrows) and macro-vesicular vacillations of crossly sectioned cardiac muscle fibers (black arrows) as shown in photo (2). These results agree with Sahraoui et al., (2016)revealed that High fat diet induced structural disorganization and interstitial edema associated with the accumulation of infiltrating cells and lipids within the myocardium, suggesting cardiomyopathy. High fat diet exacerbated myocardial interstitial and perivascular fibrosis.

Microscopic pictures of $\mathrm{H} \& \mathrm{E}$ stained heart sections showing from group received olive 5\% showing mildly congested blood vessels (red arrows), perivascular and interstitial edema (blue arrows) and few macro vesicular vacillations of crossly sectioned cardiac muscle fibers (black arrows)as shown in photo (3). Heart sections from group received olive $10 \%$ showing greatly restored histological appearance as shown in photo (4). Heart sections from group received nettle 5\% showing congestion (red arrows), perivascular and interstitial edema edema (blue arrows) with some macro vesicular vacillations of crossly sectioned cardiac muscle fibers (black arrows) as shown in photo (5). Heart sections from group received nettle $10 \%$ showing mild congestion (red arrows) as shown in photo (6). These results agree with Namazi et al., (2018) who Showed there was a significant decrease in The aortic arch thickness of 
rats in groups treated with UD In histopathological evaluations of the aortic arch, which Conclusion Ethanolic extract of UD prevents establishment of atherosclerotic lesions in rat aorta, which is associated with positive effects on serum lipid profile without significantly affecting antioxidant status. Also, Tesfaye et al ., (2021) reported The cardio protective activity of the crude extract and solvent fractions of Urticasimensis leaves were confirmed by the histopathologic examination of the cardiac tissues The cardioprotective effect could be attributed to the antioxidant activity of the plant extracts. The cardioprotective activity of solvent fractions of Urticasimensis leaves were confirmed by the histopathologic examination of the cardiac tissues of treated animals. The cardiac tissues in the normal control group showed normal morphological architecture with no cellular necrosis, interstitial space edema and hemorrhage.

\section{CONCLUSION:}

This is study evaluated the protective effect of the nettle and olive leaves on hyperlipidemia in rats. Which in the leaves of nettle and olive have contain abundant amounts of natural phenolic compounds, flavonoids, phenolic acids, anthocyanins, and other phenols, which may function as effective natural antioxidants. The consumption of nettle and olive leaves could be used for improving lipid profile, liver function and protect from hyperlipidemia in experimental rats.

\section{REFERENCES \\ AOAC (2010):}

Association of Official

Analytical Chemists. Official

Method of Analysis, 19th

Edition, Washington, D. C.

\section{Allain CC; Poon LS and ChanCS (1974): \\ Enzymatic determination of serum total cholesterol. Clin. Chem., 20:470-475.}

\section{Bergmeyer HU; Horder $M$ and Rej J (1986):}

Approved recommendation (1985) on IFCC methods for the measurement of catalytic concentration of enzymes. Part 2. IFCC method for aspartate aminotransferase (Laspartate: 2-oxoglutarate aminotransferase, EC 2.6.1.1). J. Clin. Chem. Clin. Biochem., 24:497-510.

\section{Carleton H (1979):}

"Histological Technique". 4th Ed., London. 
Chapman DG; Castilla $R$ and Campbell JA (1959):

Evaluation of protein in food. I. A method for determination of protein efficiency ratio. Can. $J$. Biochem. Physiol., 37:679689.

Draper HH; Squires EJ; Mahmoodi $\mathbf{H} \mathbf{J}$ and Agarwal $M$ (1993):

"A comparative evaluation of thiobarbituric acid methods for the determination of malondialdehyde in biological materials". Free Radicals Biol. Med., 15: 353-363.

\section{Eldamaty H (2018):}

Effect of Adding Nettle Leaves (UritcadioicaL.) powder on Basal Diet to Lower Diabetes in Rats. Egyptian Journal of Food Science, Vol. 46, pp. 141 151.

Ellman GL (1959):

"Tissue sulphydry1 groups" .Arich Biochem. Biophys., 82 : 70-77.

Elmaadawy AA and Alsadeq HA (2015):
Effect of cheese supplemented with olive leaves extract on blood lipid profile of hyperlipidemic rats. Journal of Studies and Searches of Specific Education, Volume (1) No. (2) : 133- 143.

Fan S; Raychaudhuri S; Kraus O; Shahinozzaman $M$; Lofti $L$ and Obanda DN (2020):

Urticadioica Whole

Vegetable as a Functional Food Targeting Fat Accumulation and Insulin Resistance-a Preliminary Study in a Mouse PreDiabetic Model. Nutrients 12(4):1059.

Friedwald WT; Levee RI and Fredrickson DS (1972):

Estimation of the concentration of low-density lipoprotein separated by three different methods. Clin. Chem., 18:499-502.

ki; Sayadi; Mahmoudi; Daoued I; Marrekchi and Ghorbe 1 (2020):

"Comparative Study on Beneficial Effects of Hydroxytyrosol- and Oleuropein- Rich Olive Leaf Extracts on High-Fat Diet- 
Induced Lipid Metabolism Disturbance and Liver Injury in Rats", Bio Med Research International, vol. 15 pages

Ghanem MTM; Tawfik WA; Mahdy E M; Abdelgawad ME; Abdel -Azim N S and El-Missiry MM (2019):

Chemical and biological evaluation of olive leaves as a waste by-product of olive oil industry. Egyptian Pharmaceutical Journal. Volume: 18 | Issue Number: 2 | Page: 172-177.

Giammanco M; Aiello S; Casuccio A; La Guardia M; Cicero L; Puleio R; Vazzana I; Tomasello G; Cassata G; Leto G and Di Majo D (2016):

Effects of 3,5-diiodo-1thyronine on the liver of high fat diet fed rats. Journal of Biological Research; volume 89:566

Grauso L; de Falco B; Lanzotti V and Motti R (2020):

Stinging nettle, Urticadioica L.: botanical, phytochemical and pharmacological overview. Phytochem Rev 19, 1341-1377.
Hill MF and Bordoni B (2021):

Hyperlipidemia. In: Stat Pearls Publishing LLC. Treasure Island (FL). http:/ / creativecommons.org/licens es/by/4.0/).

Jemai H; Mahmoudi A;Feryeni A;Fki I;Bouallagui Z;Choura $S$;Chamkha $M$ and Sayadi S.(2020):

Hepatoprotective Effect of Oleuropein-Rich Extract from Olive Leaves against Cadmium-Induced Toxicity in Mice. Biomed Res Int. 3;2020:4398924.

Kakkar P; Das B and Viswanathan PN (1984):

"A modified spectrophotometric assay of superoxide dismutase". Ind. J. Biochem. Biophy., 131 : 132.

Lasker S; Rahman MM; Parvez F; Zamila M; Miah P; Nahar K;KabirF;SharminSB;SubhanN; Ahsan GU and Alam MDA (2019):

High fat diet-induced metabolic syndrome and oxidative stress in obese rats 
are ameliorated by yogurt supplementation. SciRep 9, 2 0026.

\section{Li P; Lu X; Teng C; Hadley M;}

CaiP ; Dai Q and WangB (2021):

The Association between Hyperlipidemia and InHospital Outcomes in Takotsubo Cardiomyopathy. Diabetes MetabSyndr. Obes. 14:117-126.

Lopes-Virella MF; Stone, S., Ellis, S. and Collwell, J.A. (1977):

Cholesterol determination in high-density lipoprotein separated by three different methods. Clin. Chem., 23(5): 882-884.

Maria M S; Paucean A; Chis MS; Muste S; Pop A; Muresan AE and Martis G (2019):

Effect of nettle leaves powder (urticadioica 1.) addition on the quality of bread. Hop and Medicinal Plants., vol 27, no 1-2 issn. 2360-0179 print 23600187 electronic.

Melkegna TH and Jonah SA (2021):
Elemental Analysis of Medicinal Plants Used for the Treatment of Some Gastrointestinal Diseases in Ethiopia Using INAA Technique. Biol Trace Elem Res. 199(3):1207-1212.

Namazi F; Shomali T; Taghikhani $P$ and Nazifi $S$ ( 2018):

Protective effect of Urticadioica leaf hydro alcoholic extract against experimentally-induced atherosclerosis in rats. Avicenna J Phytomed; 8(3): 254-262.

Omagari K; Koba C; Nagata A; Ngo LCT ; Yamasaki M; Fukuda A; YuasaM ; Suruga K; Inada N; Shimizu MI and Tsuneyamad K (2021):

Olive leaf powder prevents nonalcoholic steatohepatitis in SpragueeDawley rats fed a high fat and high-cholesterol diet. Clinical Nutrition Open Science, volume37, p 47-59.

Paulauskienè A; Tarasevičienè $\check{Z}$ and Laukagalis V (2021):

Influence of Harvesting Time on the Chemical Composition of Wild 
Stinging

Nettle

(Urticadioica L.). Plants, 10, 686.

Ranieri M; Di MiseA; Centrone M; D'Agostino M; Tingskov JS; Venneri M; Pellegrino T; Difonzo G; Caponio F; Norregaard R; Valenti $G$ and Tamma G (2021):

Olive Leaf Extract (OLE) impaired vasopressin induced aquaporin-2 trafficking through the activation of the calcium-sensing receptor. Sci Rep 11, 4537 .

\section{Rashwan NM (1994):}

Special Diet for Inducing Hypercholesterolemia, Ph.D. Thesis, Nutrition and Food Science Dep. Faculty of Home Economics. Helwan University

Reeves PG; Nielsen FH and Fahey GC (1993):
AIN-93 purified diets for laboratory rodents: Final report of the American Institute of Nutrition Ad Hoc Writing Committee on the Reformulation of the AIN- 76A Rodent Diet. J. Nutr., 123(11): 1939-1951.

Repajić M; Cegledi E, Zorić Z; Pedisić S; Garofulić IE; Radman S; Palčić I and Uzelac DV(2021):

Bioactive Compounds in Wild Nettle (Urticadioica L.) Leaves and Stalks: Polyphenols and Pigments upon Seasonal and Habitat Variations. Foods 2021; 10(1):190.

Roy SE (1970):

Colorimetric determination of serum alkaline phosphatase". Clin. Chem., 16:431-432.

Sahraoui A; Dewachter C; de Medina G; Naeije R; Aouichat Bouguerra $S$ and Dewachter $L$ (2016):

Myocardial Structural and Biological Anomalies Induced by High Fat Diet in Psammomysobesus Gerbil s. PLOS ONE 11(2): e0148117.

SakrS; Abdel-Aziz K; El-kott Aand Khalifa H (2016):

Ameliorative effect of olive leaves extract on hepatotoxicity and oxidative stress in streptozotocininduced diabetic 
rats.. Journal of Bioscience and Applied Research, 2016; 2(8): 549-560.

Salama Z A; Aboul-Enein AM; Gaafar A A; Asker MA; Aly H F and Ahmed HA (2020):

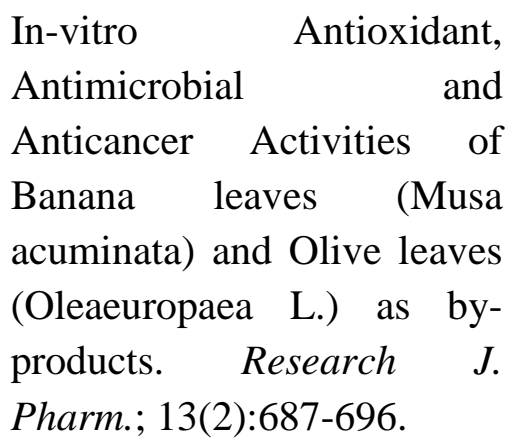

Shaheen KAA and Elkersh MSM (2019):

Potential effect of some fruit leaves to reduce weight in obese experimental animals. Journal of Home Economics, Volume 29, Number (1).

Shah S ; Nisar Z ; Nisar J ;Akram M ; GhotekarS and Oza R ( 2021):

Nanobiomedicine: A New Approach of Medicinal Plants and Their Therapeutic Modalities. J. Mater. Environ. Sci. 12(1): 01-14.
Statistical methods "Fourth Ed., The low state, college press, Ames lowa.

Tarola AM; Van de Velde F; Salvagni L and Pretti R (2013):

Determination of phenolic compounds in strawberries (Fragariaananassa Duch) by high performance liquid chromatography with diode array detection. Food Anal. Methods,6:227-237.

Tek NA and Ağagündüz D ( 2020):

Olive Leaf (Oleaeuropaea L. folium): Potential Effects on Glycemia and Lipidemia. Annals of Nutrition and Metabolism An interdisciplinary journal on human and clinical nutrition, 76:1015

Telo S; Halifeoglu I and Ozercan IH (2017):

Effects of Stinging Nettle (UrticaDioica L.,) on Antioxidant Enzyme Activities in Rat Model of Mammary Gland Cancer. Iran J Pharm Res.16 (Supp 1):164-170.

Snedecor GW (1969): 
Tesfaye BA; Berhe AH, Wondafrash DZ and Berhe DF (2021):

Cardio protective Effect of

Crude Extract and Solvent

Fractions of Urticasimensis .

Leaves on Cyclophos-

phamide- Induced Myo-

cardial Injury in Rats. $J$ Exp.

Pharmacol. 13:147-160.

\section{Tilvis RS and Miettinen TA} (1986):

"Serum plant sterols and their relation to cholesterol absorption". Am. J. Clin. Nutr., 43: 92-97.

\section{Trinder P (1959):}

"Determination of blood glucose using 4aminophenazone". J. Clin. Path., 22:246 .

\section{Trinder $P$ and Ann S (1969):}

Enzymatic Colorimetric test with lipid clearing factor to determine triglycerides. Clin.Biochem, 6:24-27. 
Table 1: The averages of moisture, protein, fat, carbohydrate and ash (g/100g) dryin nettle and olive leave powder

\begin{tabular}{|l|l|l|}
\hline \multicolumn{1}{|c|}{$\begin{array}{c}\text { Proximate } \\
\text { composition }(\mathrm{g} / 100 \mathrm{~g})\end{array}$} & nettle leaves & olive leaves \\
\hline Moisture & 9.4 & $\mathbf{7 . 1}$ \\
\hline Crude protein & 18.60 & $\mathbf{1 0 . 3 6}$ \\
\hline Crude fat & 1.15 & $\mathbf{3 . 4 2}$ \\
\hline Ash & 41.61 & $\mathbf{8 . 3 9}$ \\
\hline Carbohydrate & 29.24 & $\mathbf{6 9 . 7 3}$ \\
\hline Fiber & 17.16 & $\mathbf{2 2 . 6 0}$ \\
\hline
\end{tabular}

Table 2: The phenolic and flavonoids profiles in Urticadioica

\begin{tabular}{|l|l|l|l|}
\hline Flavonoids & $\mathrm{mg} / \mathrm{g}$ leaves & Penolic acids & $\mathrm{mg} / \mathrm{g}$ leaves \\
\hline Pyrogallol & - & Gallic acid & $\mathbf{6 . 7 4 1 2 6}$ \\
\hline Quinol & 18.75611 & $\begin{array}{l}\text { p- } \\
\text { benzoic acid }\end{array}$ & $\mathbf{3 1 . 9 7 5 9 4}$ \\
\hline 3-Hydroxytyrosol & 148.37622 & Vanillic acid & - \\
\hline Catechol & 29.86980 & Caffeic acid & $\mathbf{4 . 4 1 4 0 0}$ \\
\hline Catechin & 8.31606 & Syringic acid & $\mathbf{6 . 8 9 3 4 1}$ \\
\hline Chlorogenic & - & p- Coumaric acid & $\mathbf{3 . 7 8 9 8 1 e - 1}$ \\
\hline Rutin & - & Benzoic acid & $\mathbf{1 1 3 7 . 9 7 2 0 5}$ \\
\hline Ellagic & 25.24869 & Ferulic acid & $\mathbf{4 . 7 7 4 8 4}$ \\
\hline Resvertol & 53.28780 & o- Coumaric acid & $\mathbf{1 1 . 6 1 9 1 4}$ \\
\hline Quercitin & 102.62865 & Cinnamic acid & $\mathbf{1 . 0 0 4 3 5}$ \\
\hline rosemarinic & 420.34409 & & \\
\hline Neringein & 261.62098 & & \\
\hline Myricetin & 189.87756 & & \\
\hline Kampherol & 22.11440 & & \\
\hline
\end{tabular}




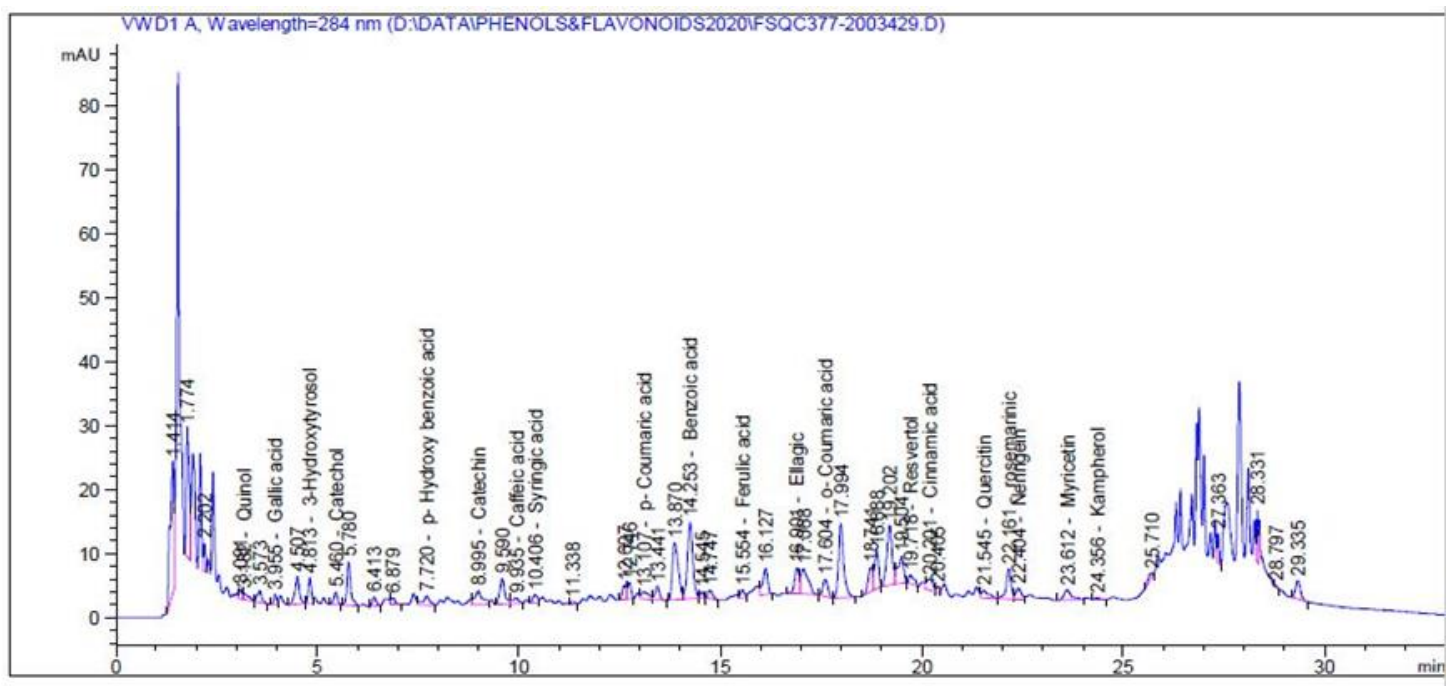

Fig 1. Phenols \& flavonoids of nettle leaves

Table 3: The phenolic and flavonoids profiles in olive leaves

\begin{tabular}{|l|l|l|l|}
\hline Flavonoids & $\mathrm{mg} / \mathrm{g}$ leaves & Penolic acids & $\mathrm{mg} / \mathrm{g}$ leaves \\
\hline Pyrogallol & - & Gallic acid & - \\
\hline Quinol & - & $\begin{array}{l}\text { p- Hydroxy } \\
\text { benzoic acid }\end{array}$ & $\mathbf{1 8 2 . 7 1 3 9 9}$ \\
\hline 3-Hydroxytyrosol & 430.31062 & Vanillic acid & $\mathbf{1 0 2 . 0 1 7 4 0}$ \\
\hline Catechol & 280.73027 & Caffeic acid & $\mathbf{1 5 7 . 4 6 6 6 7}$ \\
\hline Catechin & - & Syringic acid & - \\
\hline Chlorogenic & 61.71219 & p- Coumaric acid & - \\
\hline Rutin & 809.39698 & Benzoic acid & $\mathbf{1 1 5 3 . 6 1 1 5 7}$ \\
\hline Ellagic & 1916.31634 & Ferulic acid & $\mathbf{4 0 . 4 3 5 2 8}$ \\
\hline Resvertol & 609.78548 & o- Coumaric acid & $\mathbf{1 1 1 . 5 7 7 4 6}$ \\
\hline Quercitin & 1288.72774 & Cinnamic acid & $\mathbf{2 9 . 6 1 7 8 1}$ \\
\hline rosemarinic & 3181.04967 & & \\
\hline Neringein & - & & \\
\hline Myricetin & 1232.29864 & & \\
\hline Kampherol & 621.19737 & & \\
\hline
\end{tabular}




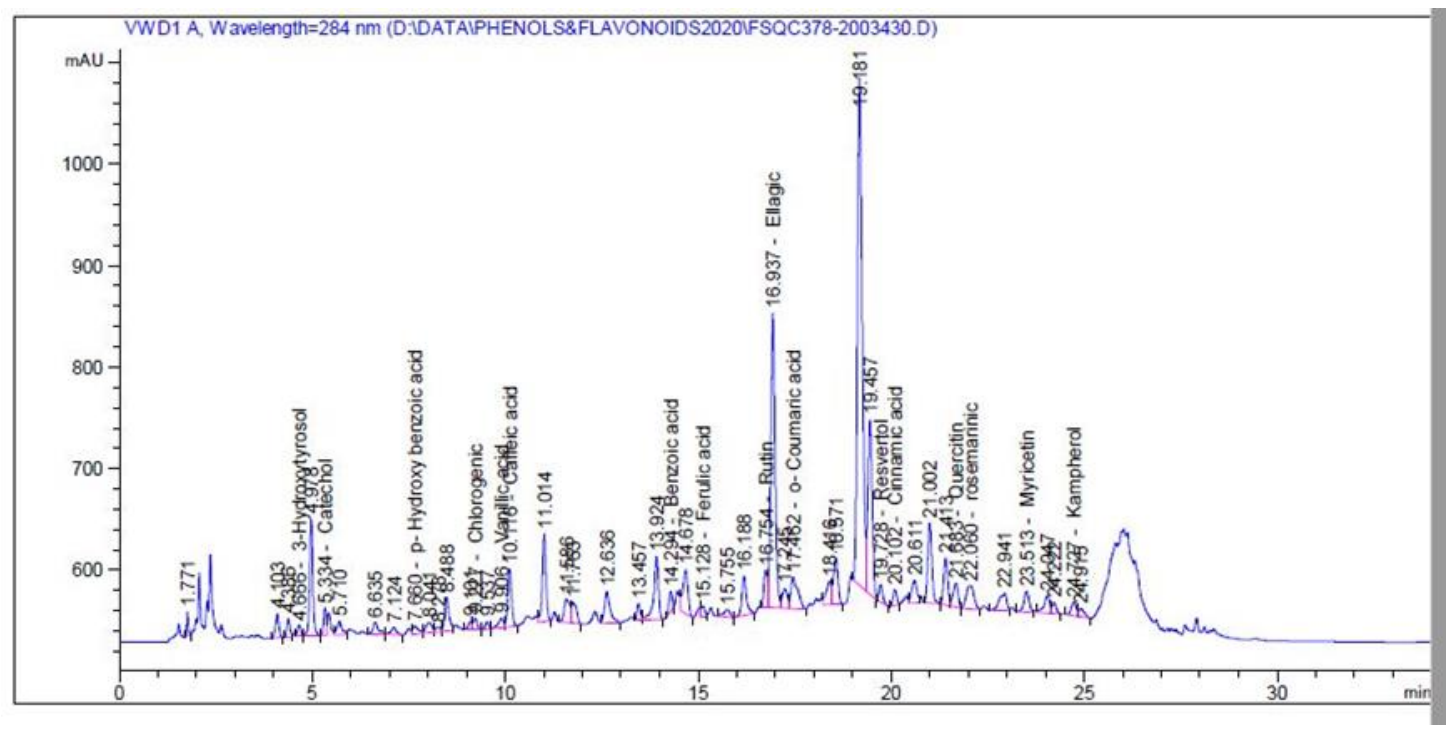

Fig 2. Phenols \& flavonoids of olive leaves

Table 4: Protective effect of nettle and olive leaves on body weight gain (BWG \%) and feed efficiency ratio (FER) of hyperlipidemia rats ( $\mathrm{n}=6$ rats)

\begin{tabular}{|c|c|c|c|}
\hline $\begin{array}{l}\text { Parameters } \\
\text { Groups }\end{array}$ & FI (g) & BWG (\%) & FER \\
\hline Control-ve & $20.95 \pm 2.38^{\mathrm{f}}$ & $42.93 \pm 12.35^{\mathrm{c}}$ & $.087 \pm .02^{\mathrm{c}}$ \\
\hline Control + ve & $23.23 \pm 2.94^{\mathrm{b}}$ & $78.23 \pm 19.66^{a}$ & $0.15 \pm .02^{\mathrm{a}}$ \\
\hline Nettle $5 \%$ & $22.8 \pm 4.26^{\mathrm{c}}$ & $73.03 \pm 12.78^{\mathrm{a}}$ & $0.14 \pm .015^{\mathrm{ab}}$ \\
\hline Nettle $10 \%$ & $27.6 \pm 6.44^{\mathrm{a}}$ & $53.97 \pm 9.50^{\mathrm{bc}}$ & $0.09 \pm .012^{c}$ \\
\hline Olive $5 \%$ & $22.4 \pm 7.49^{d}$ & $63.25 \pm 16.24^{\mathrm{ab}}$ & $0.12 \pm .02^{b}$ \\
\hline Olive $10 \%$ & $21.23 \pm 5.93^{\mathrm{e}}$ & $46.70 \pm 14.12^{\mathrm{bc}}$ & $.09 \pm .02^{\mathrm{c}}$ \\
\hline LSD & 6.19 & 17.06 & 0.02 \\
\hline
\end{tabular}

Values denote arithmetic means $\pm S D$. Means with different letters (in the same column are significantly at $(p \leq 0.05)$ using one-way ANOVA test, while those with similar letters are nonsignificant. 
Table 5: Protective effect of nettle and olive leaves on Total cholesterol (T.C) and Triglycerides (T.G) of hyperlipidemic rats ( $n=6$ rats)

\begin{tabular}{|c|c|c|}
\hline $\begin{array}{c}\text { parameters } \\
\text { Groups }\end{array}$ & $\begin{array}{l}\text { Total cholesterol } \\
(\mathrm{mg} / \mathrm{dl})\end{array}$ & $\begin{array}{l}\text { Triglycerides } \\
(\mathrm{mg} / \mathrm{dl})\end{array}$ \\
\hline Control - ve & $68.0 \pm 7.87^{\mathrm{d}}$ & $86.16 \pm 12.38^{d}$ \\
\hline Control + ve & $150.8 \pm 11.90^{\mathrm{a}}$ & $200.5 \pm 22.58^{\mathrm{a}}$ \\
\hline Nettle $5 \%$ & $116.3 \pm 15.90^{b}$ & $153.6 \pm 22.43^{b}$ \\
\hline Nettle $10 \%$ & $89.0 \pm 9.31^{\mathrm{c}}$ & $118.3 \pm 17.61^{c}$ \\
\hline Olive $5 \%$ & $112.0 \pm 10.80^{\mathrm{b}}$ & $145.83 \pm 16.30^{b}$ \\
\hline Olive $10 \%$ & $75.3 \pm 5.78^{\mathrm{d}}$ & $106.66 \pm 14.19^{\mathrm{cd}}$ \\
\hline LSD & 12.6 & 21.23 \\
\hline
\end{tabular}

Values denote arithmetic means $\pm S D$. Means with different letters (in the same column are significantly at $(p \leq 0.05)$ using one-way ANOVA test, while those with similar letters are nonsignificant.

Table 6: Protective effect of nettle and olive leaves on lipoprotein fractions (HDL-C, LDL-C, VLDL-C) and atherogenic index (AI) of hyperlipidemia

\begin{tabular}{|c|c|c|c|c|}
\hline Proups & $\begin{array}{l}\text { HDL-C } \\
\mathrm{mg} / \mathrm{dl}\end{array}$ & $\begin{array}{l}\text { LDL-C } \\
\mathrm{mg} / \mathrm{dl}\end{array}$ & $\begin{array}{l}\text { VLDL-C } \\
\mathrm{mg} / \mathrm{dl}\end{array}$ & AI \\
\hline Control - ve & $47.33 \pm 4.41^{\mathrm{a}}$ & $7.36 \pm 4.12^{\mathrm{d}}$ & $17.23 \pm 2.47^{\mathrm{d}}$ & $.445 \pm .163^{\mathrm{e}}$ \\
\hline Control + ve & $32.00 \pm 5.79^{c}$ & $78.73 \pm 10.52^{a}$ & $40.10 \pm 4.51^{\mathrm{a}}$ & $3.82 \pm .781^{a}$ \\
\hline Nettle 5\% & $34.16 \pm 4.26^{\mathrm{bc}}$ & $51.43 \pm 10.98^{b}$ & $30.73 \pm 4.48^{b}$ & $2.43 \pm .552^{b}$ \\
\hline Nettle $10 \%$ & $45.00 \pm 4.93^{\mathrm{a}}$ & $20.33 \pm 7.22^{\mathrm{c}}$ & $23.67 \pm 3.52^{\mathrm{c}}$ & $.995 \pm .277^{\mathrm{d}}$ \\
\hline Olive 5\% & $38.83 \pm 4.26^{\mathrm{b}}$ & $44.0 \pm 4.21^{\mathrm{b}}$ & $29.17 \pm 3.26^{b}$ & $1.89 \pm .157^{c}$ \\
\hline Olive $10 \%$ & $45.33 \pm 4.41^{\mathrm{a}}$ & $8.66 \pm 2.93^{\mathrm{d}}$ & $21.33 \pm 2.83^{\mathrm{cd}}$ & $.671 \pm .154^{\mathrm{de}}$ \\
\hline LSD & 5.56 & 8.5 & 4.24 & 0.49 \\
\hline
\end{tabular}

Values denote arithmetic means $\pm S D$. Means with different letters (in the same column are significantly at $(p \leq 0.05)$ using one-way ANOVA test, while those with similar letters are nonsignificant. 
Table 7: Protective effect of nettle and olive leaves on SOD, GPX and MDA of hyperlipidemic rats $(n=6$ rats $)$

\begin{tabular}{|c|c|c|c|}
\hline Groups & SOD U/L & $\mathrm{GP}_{X} \mathrm{ng} / \mathrm{ml}$ & $\begin{array}{l}\text { MDA } \\
\mathrm{m} \mathrm{mol} / \mathrm{gm}\end{array}$ \\
\hline Control - ve & $52.06 \pm 3.826^{\mathrm{a}}$ & $91.4 \pm 6.82^{\mathrm{a}}$ & $10.5 \pm 2.41^{\mathrm{d}}$ \\
\hline Control + ve & $27.46 \pm 3.75^{\mathrm{d}}$ & $54.03 \pm 7.11^{\mathrm{d}}$ & $26.4 \pm 3.66^{a}$ \\
\hline Nettle $5 \%$ & $36.23 \pm 6.13^{c}$ & $64.3 \pm 8.24^{c}$ & $21.3 \pm 2.71^{b}$ \\
\hline Nettle $10 \%$ & $42.43 \pm 5.52^{\mathrm{bc}}$ & $82.3 \pm 3.74^{b}$ & $12.4 \pm 2.07^{d}$ \\
\hline Olive $5 \%$ & $39.40 \pm 5.88^{\mathrm{bc}}$ & $70.3 \pm 5.78^{c}$ & $17.2 \pm 1.55^{\mathrm{c}}$ \\
\hline Olive $10 \%$ & $45.63 \pm 5.25^{\mathrm{b}}$ & $83.7 \pm 7.97^{\mathrm{ab}}$ & $13.1 \pm 1.32^{\mathrm{d}}$ \\
\hline LSD & 6.07 & 8 & 2.8 \\
\hline
\end{tabular}

Values denote arithmetic means $\pm S D$. Means with different letters (in the same column are significantly at $(p \leq 0.05)$ using one-way ANOVA test, while those with similar letters are nonsignificant.

Table 8: Protective effect of nettle and olive leaves on serum liver function enzymes of hyperlipidemic rats $(n=6$ rats)

\begin{tabular}{|c|c|c|c|}
\hline Groups & AST U/L & ALT U/L & ALP U/L \\
\hline Control - ve & $70.67 \pm 12.92^{\mathrm{d}}$ & $26.6 \pm 6.86^{\mathrm{d}}$ & $126.0 \pm 23.7^{d}$ \\
\hline Control + ve & $185.33 \pm 31.65^{a}$ & $61.5 \pm 12.21^{\mathrm{a}}$ & $258.1 \pm 38.9^{a}$ \\
\hline Nettle 5\% & $142.33 \pm 20.22^{b}$ & $50.1 \pm 9.45^{\mathrm{b}}$ & $216.1 \pm 31.5^{b}$ \\
\hline Nettle $10 \%$ & $105.83 \pm 14.83^{\mathrm{c}}$ & $39.1 \pm 9.10^{\mathrm{bc}}$ & $169.3 \pm 19.9^{c}$ \\
\hline Olive $5 \%$ & $123.50 \pm 19.72^{b}$ & $44.6 \pm 9.77^{\mathrm{bc}}$ & $190.3 \pm 32.2^{b c}$ \\
\hline Olive $10 \%$ & $98.83 \pm 17.03^{\mathrm{c}}$ & $35.6 \pm 5.24^{\mathrm{cd}}$ & $160.5 \pm 19.7^{\mathrm{c}}$ \\
\hline LSD & 23.9 & 10.67 & 33.7 \\
\hline
\end{tabular}

Values denote arithmetic means $\pm S D$. Means with different letters (in the same column are significantly at $(p \leq 0.05)$ using one-way ANOVA test, while those with similar letters are nonsignificant. 
Table 9: Protective effect of nettle and olive leaves on serum glucose of hyperlipdemic rats $(n=6$ rats $)$

\begin{tabular}{|c|c|}
\hline Groups & $\begin{array}{l}\text { Serum Glucose } \\
(\mathrm{mg} / \mathrm{dl})\end{array}$ \\
\hline Control-ve & $78.1 \pm 10.79^{d}$ \\
\hline Control + ve & $136.5 \pm 22.1^{\mathrm{a}}$ \\
\hline Nettle 5\% & $116.0 \pm 14.02^{b}$ \\
\hline Nettle $10 \%$ & $94.6 \pm 13.17^{\mathrm{cd}}$ \\
\hline Olive $5 \%$ & $108.5 \pm 17.07^{b c}$ \\
\hline Olive $10 \%$ & $93.3 \pm 8.80^{\text {cd }}$ \\
\hline \begin{tabular}{|l|l} 
LSD \\
\end{tabular} & 17.6 \\
\hline
\end{tabular}

Values denote arithmetic means $\pm S D$. Means with different letters (in the same column are significantly at $(p \leq 0.05)$ using one-way ANOVA test, while those with similar letters are nonsignificant. 
- Liver tissue

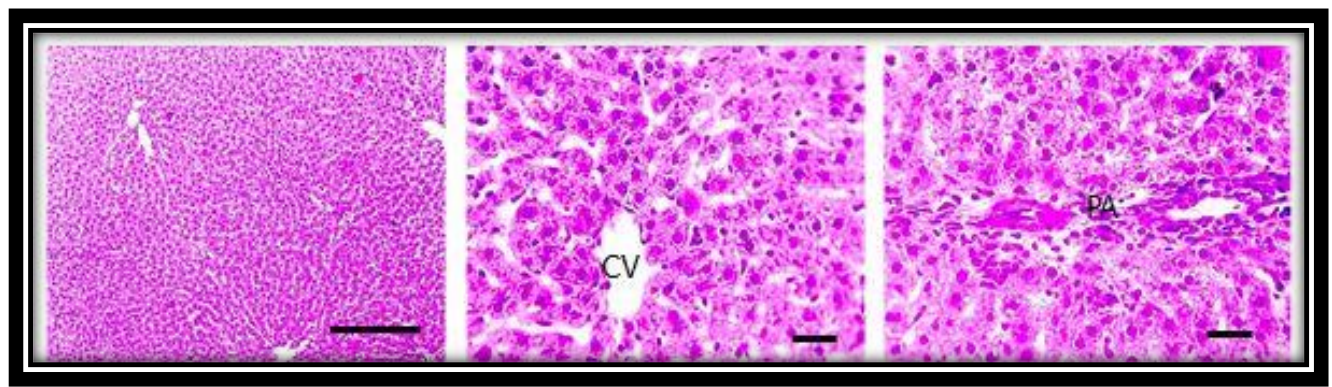

Photo 1: Microscopic pictures of H\&E stained liver sections showing normal hepatic architecture with radially arranged hepatic cords around central veins $(C V)$ with normal portal areas (PA) and sinusoids in control normal group.

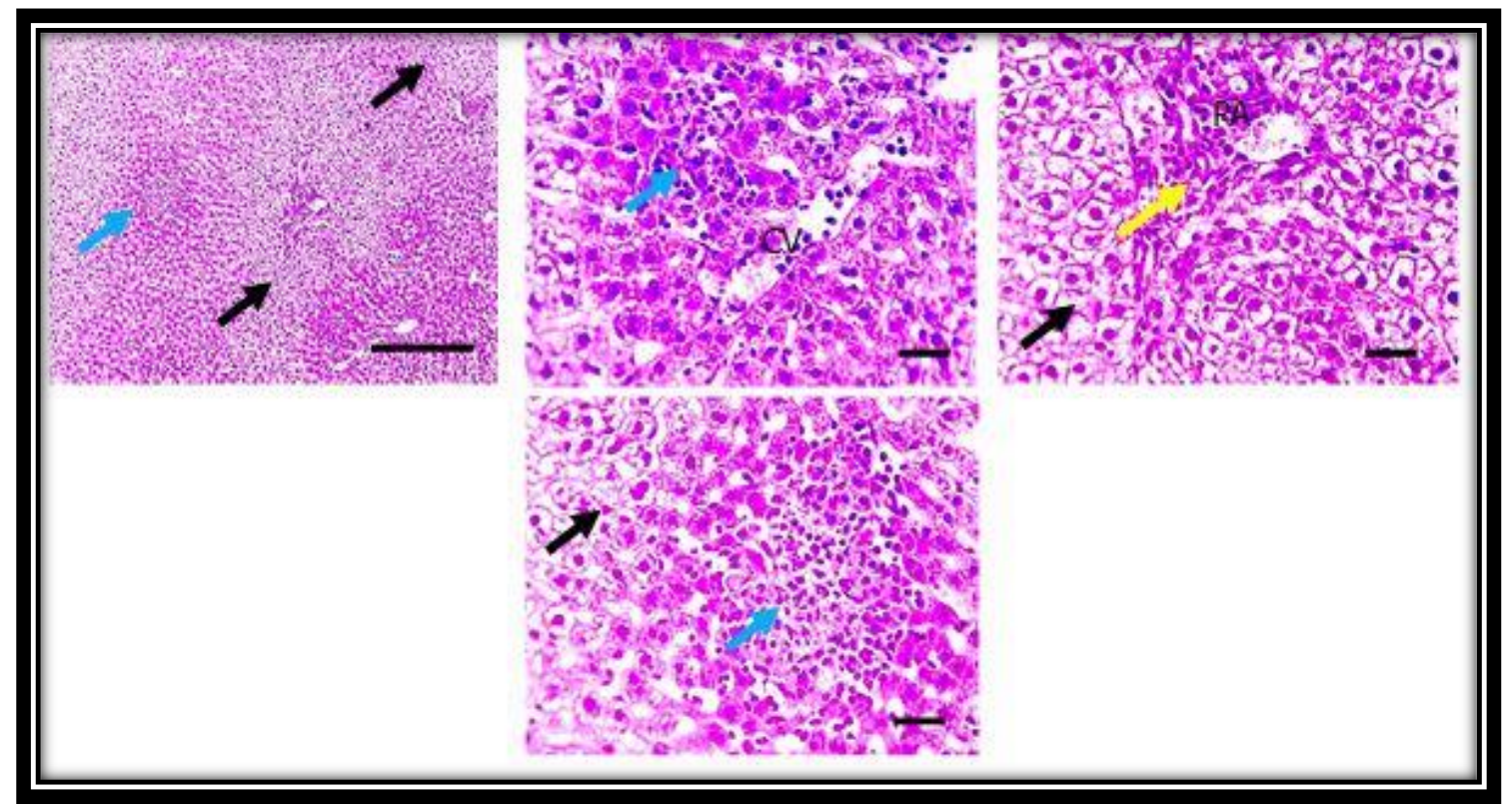

Photo 2: liver sections from untreated rat group kept on Liver sections of +ve group showing highly disrupted hepatic architecture due to diffuse ballooning degeneration (black arrows) with multifocal necrosis (blue arrows) of hepatocytes, portal inflammation (yellow arrows). 


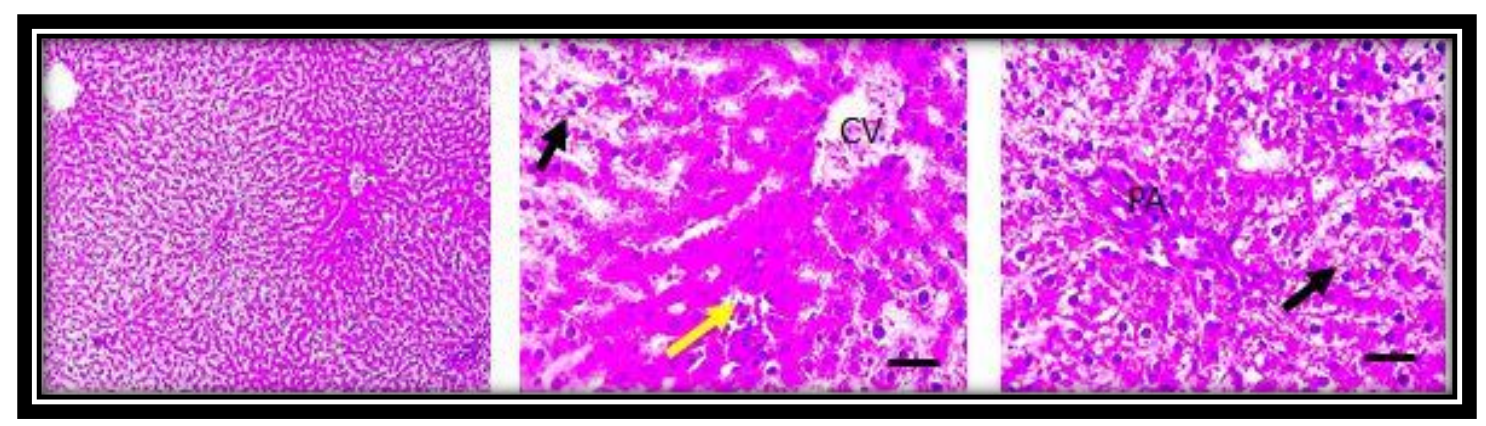

Photo 3: Liver sections from group treated with olive5\% showing mildly disrupted hepatic architecture due to moderate periportalhydropic degeneration (black arrows) of hepatocytes and mild lobular inflammation (yellow arrows).

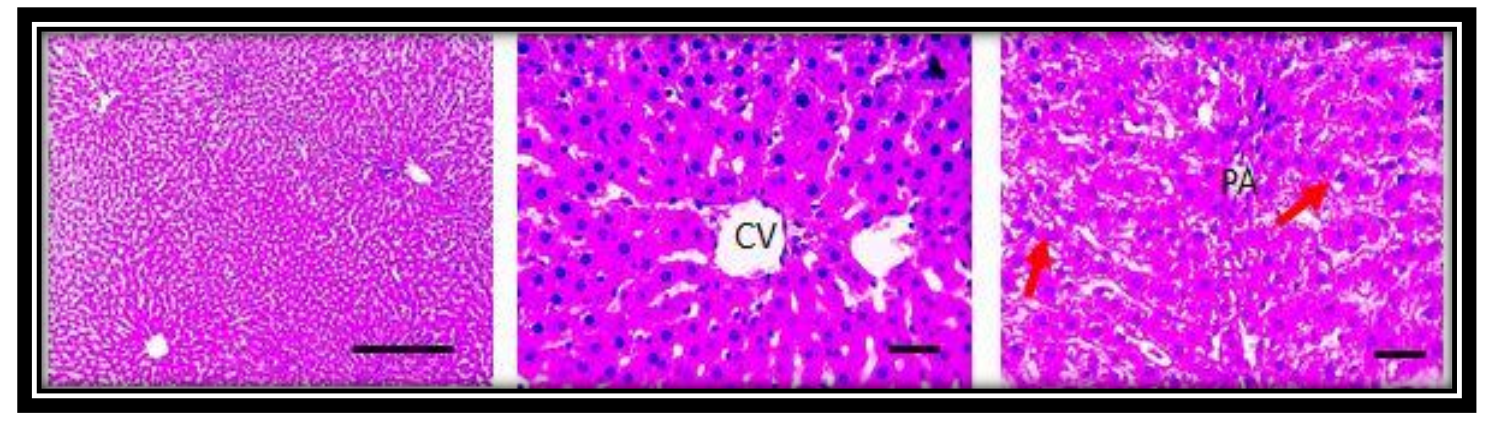

Photo 4: Liver sections from group treated with olive $10 \%$ showing greatly restored hepatic architecture with few cytoplasmic vacuoles (red arrows) in hepatocytes around PA. 


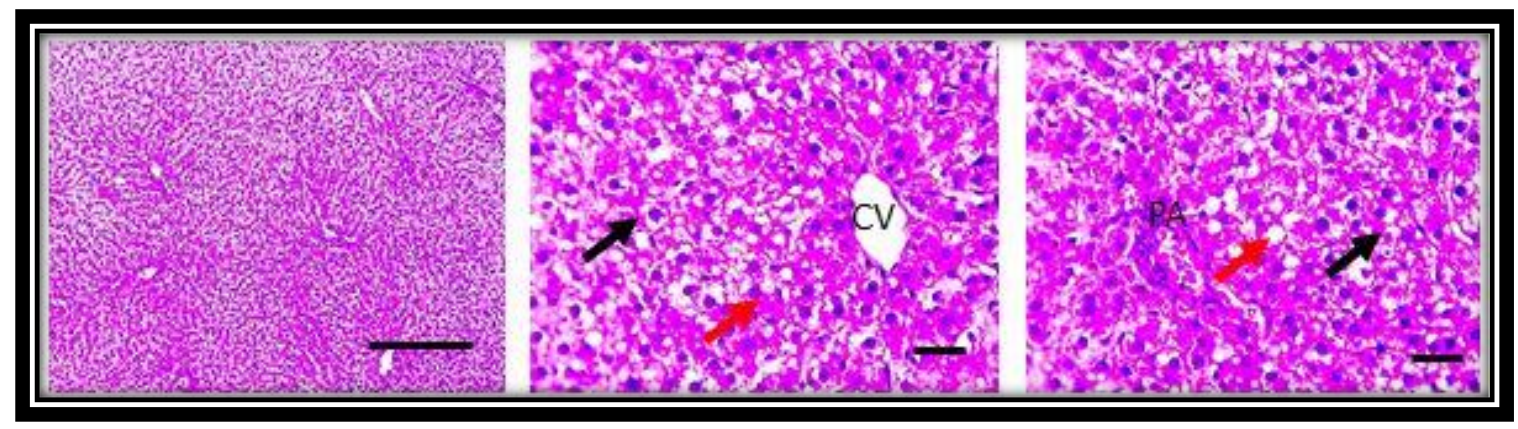

Photo 5: Liver sections from group treated with nettle 5\% moderately disrupted hepatic architecture due to hydropic degeneration (black arrows) and large cytoplasmic vacuoles in hepatocytes (red arrows) around CV and PA.

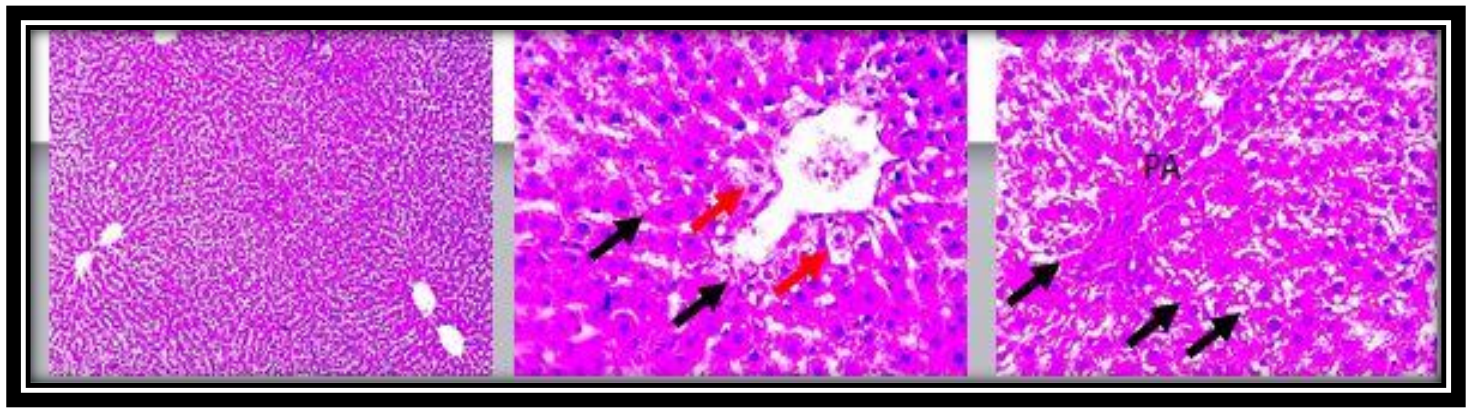

Photo 6: Liver sections from group treated with nette 10\% showing partially restored hepatic architecture with few minute cytoplasmic vacuoles in hepatocytes around $C V$ (red arrows) and mild hydropic degeneration in hepatocytes (black arrows) around PA. 


\section{- Heart tissue}

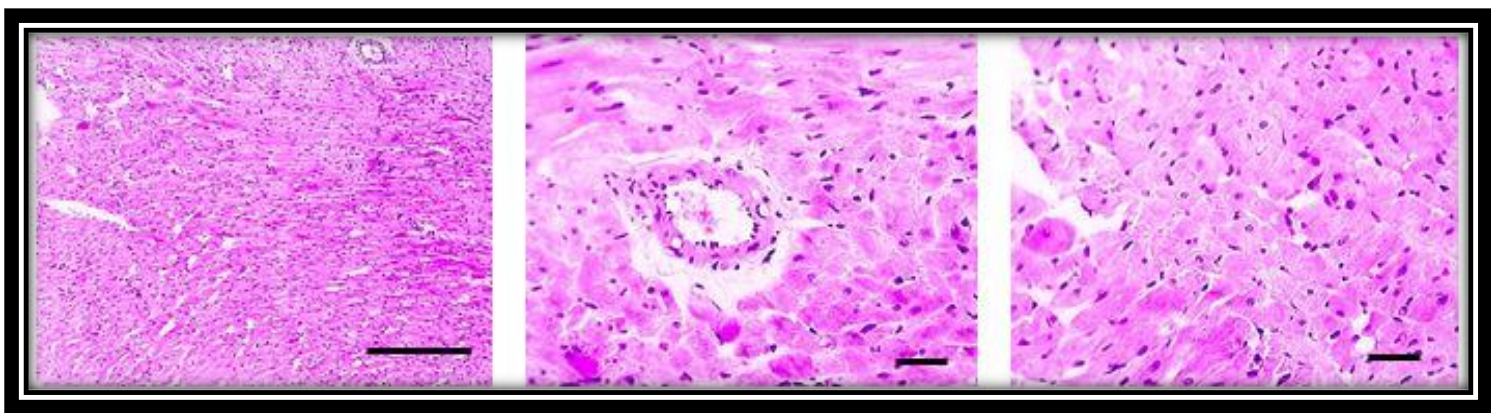

Photo 1: Microscopic pictures of H\&E stained heart sections showing normal longitudinally and crossly sectioned cardiac muscle fibers with normal blood vessels and interstitial tissue in control normal group.

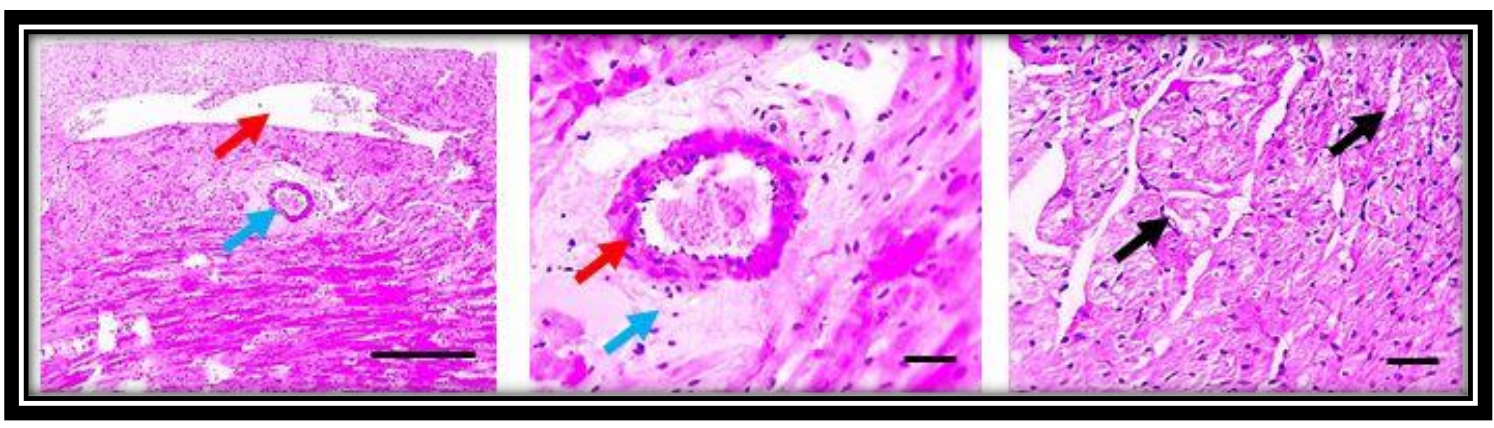

Photo 2: Heart sections of +ve group showing congested blood vessels (red arrows), marked perivascular edema (blue arrows) and macro vesicular vacillations of crossly sectioned cardiac muscle fibers (black arrows). 


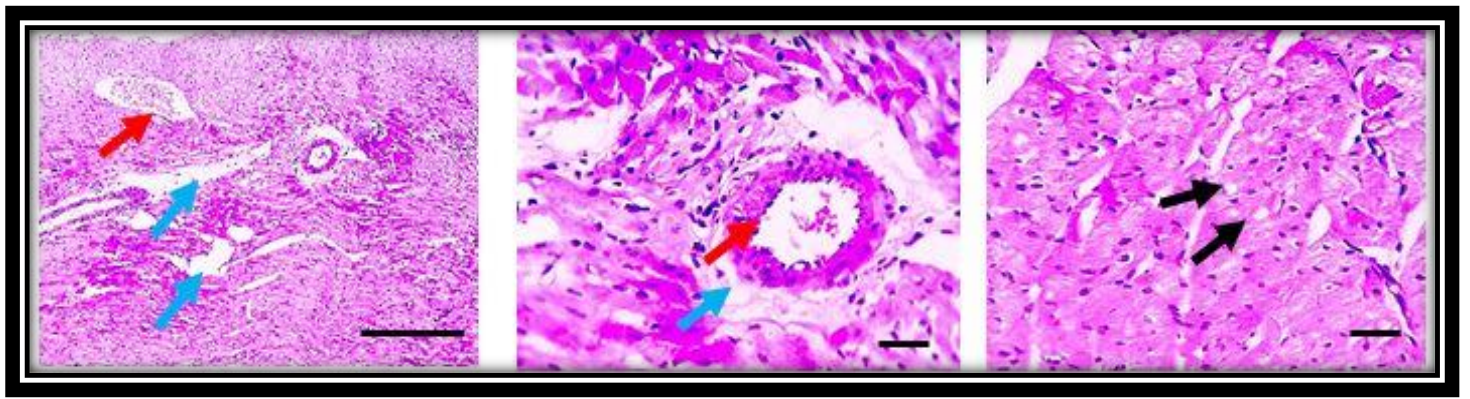

Photo 3: Heart sections from group treated with olive 5\% showing mildly congested blood vessels (red arrows), perivascular\& interstitial edema (blue arrows) and few macrovesicular vacuolations of crossly sectioned cardiac muscle fibers (black arrows).

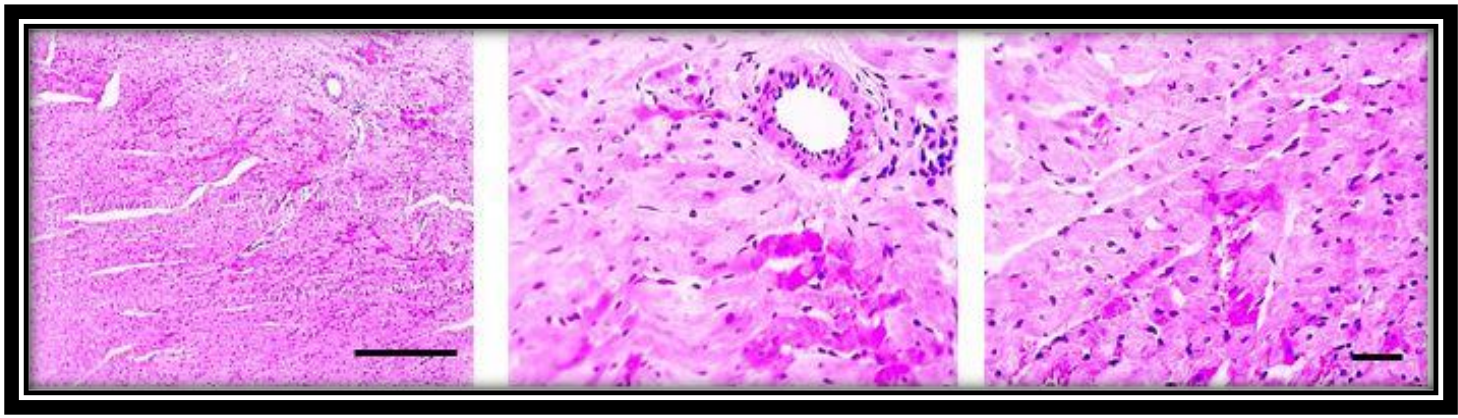

Photo 4: Heart sections from group treated with olive 10\% showing showing greatly restored histological appearance. 


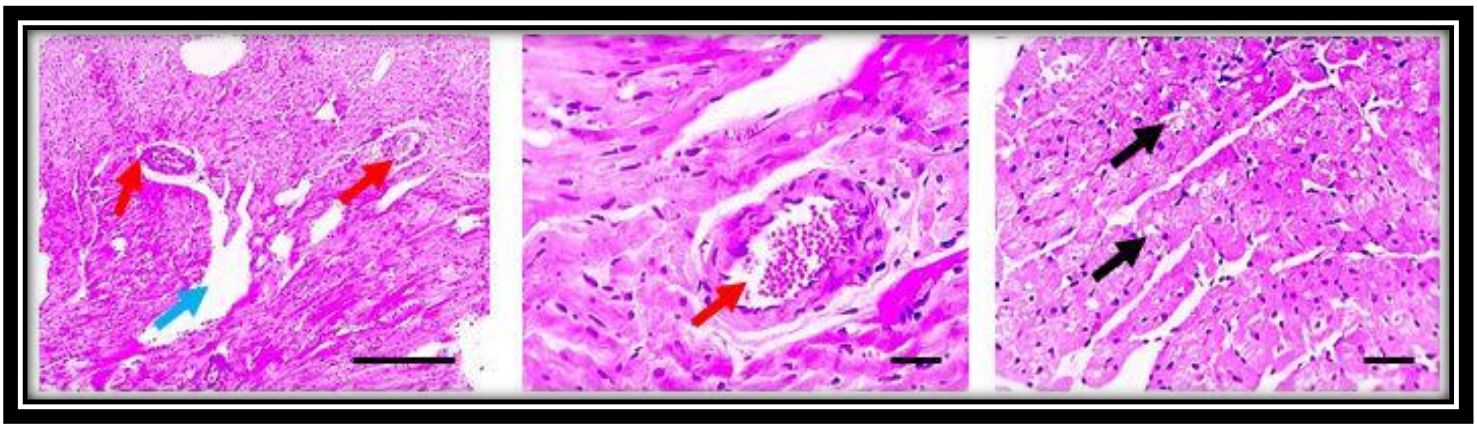

Photo 5: Microscopic pictures of $H \& E$ stained heart sections showing from group treated with nettle 5\% congestion (red arrows), perivascular\&interstitial edema edema (blue arrows) with some macrovesicularvacuolations of crossly sectioned cardiac muscle fibers (black arrows).

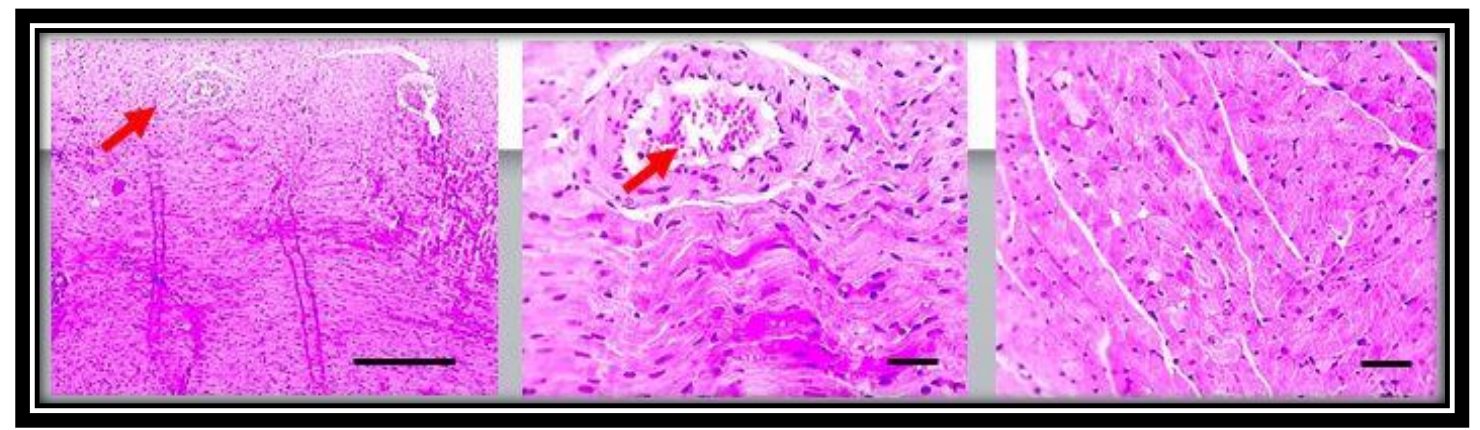

Photo 6: Heart sections from group treated with nettle $10 \%$ showing mild congestion (red arrows). 


\section{التأثير الوقائي لأوراق نبات القراص والزيتون على ارتفاع دهون

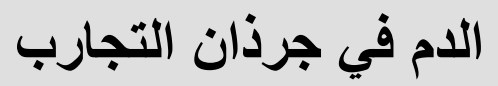

آية صلاح الدين محمد أنيس حفيظ ، سوزان عبد الرحمن سعد ، سوزان سامي ابراهيم قسم التغذية وعلوم الأطعمة ـ كلية الاقتصاد المنزلي - جامعة الأزهر- مصر. الملخص العربي

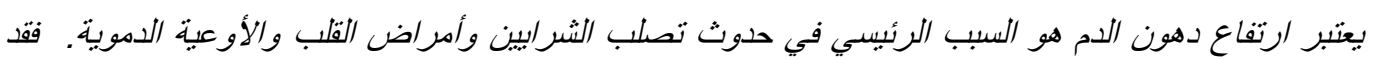

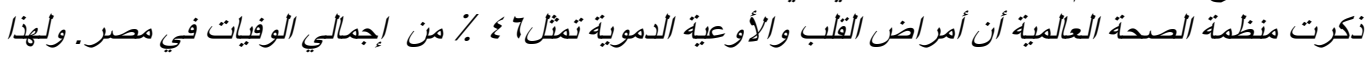

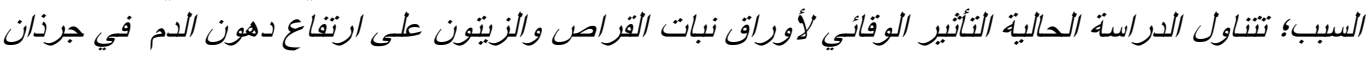

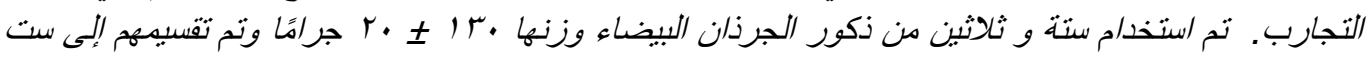

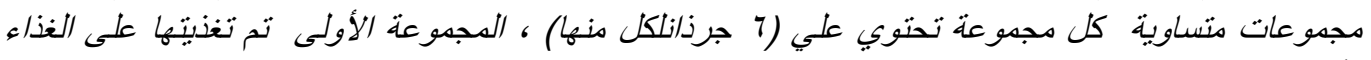

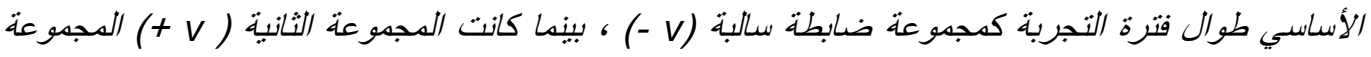

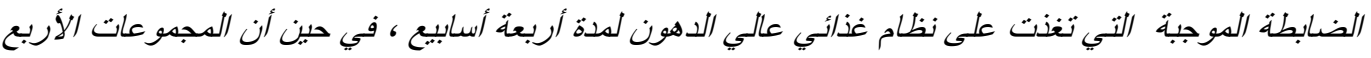

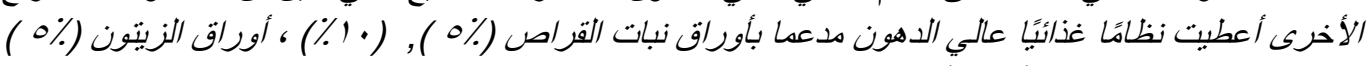

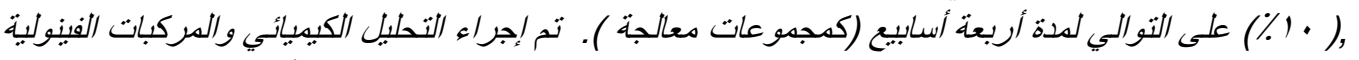

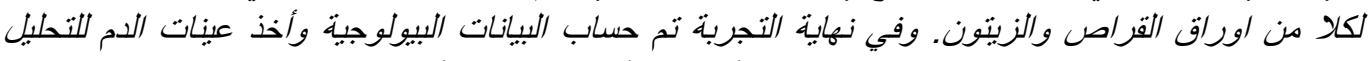

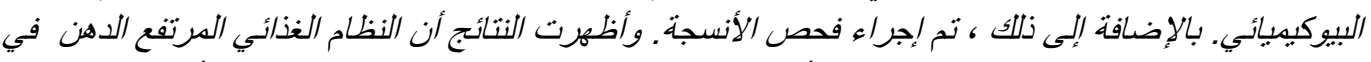

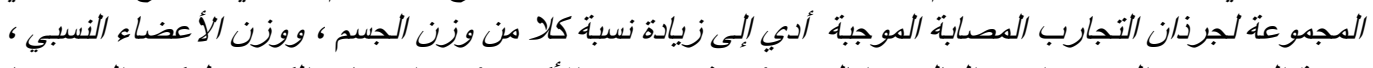

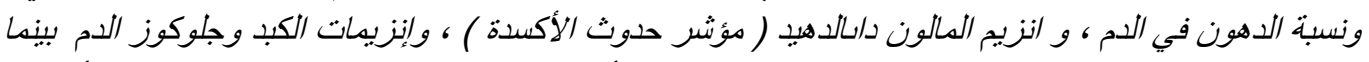

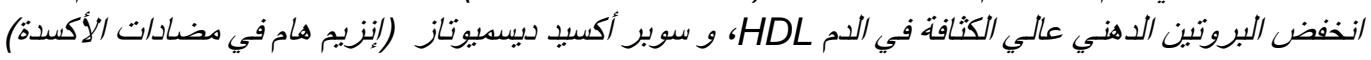

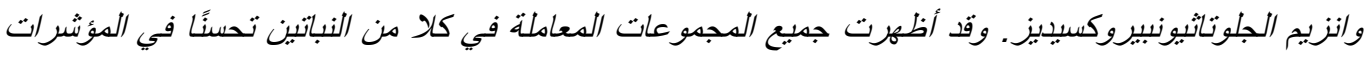

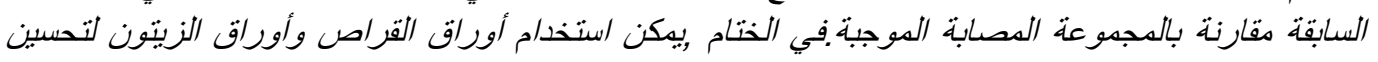

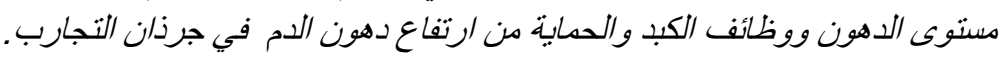

الكلمات المفتاحية:: صورة الدهون - أوراق نبات القراص / الزبتون - أنزبيات مضادات الأكسدة - وظائف الكببر 